\title{
Pengaruh Gaya Komunikasi Pustakawan Terhadap Minat Kunjung Pemustaka di Perpustakaan Universitas Islam Negeri Sulthan Thaha Saifuddin Jambi
}

\author{
1Jariah, Rory Ramayanti² \\ ${ }_{1,2}^{1,2}$ Fakultas Adab, Universitas Islam Negeri Sulthan Thaha Saifuddin Jambi \\ Jalan Jambi - Muaro Bulian Km.16, Muaro Jambi, 36363 \\ e-mail: jariyah.ryh@gmail.com
}

\begin{abstract}
Introduction. This study aims to determine whether the librarian's communication style at the State Islamic University Library of Sulthan Thaha Saifuddin Jambi affects the interest of visiting visitors. This is based on the importance of communication which is a basic need of humans as social beings, and an important part of the library, especially in serving users.

Data Collection Method. This study uses quantitative methods with data collection techniques used, namely questionnaires, observation, and documentation. The questionnaire in this study used a Likert scale. The population of this research is 8129 active students and the sample used is 99 . The sample technique of this research uses incidental sampling technique.

Data Analysis. The data analysis technique used descriptive data analysis with simple regression analysis techniques. To determine the presence or absence of influence in this study using hypothesis testing.

Result and Discussion. The results of this study are the librarian's communication style variable obtained a score percentage of $78.29 \%$ which means that the influence of the librarian's communication style is in the very high category. The variable of visiting interest obtained a percentage score of $80.24 \%$, which means that visiting interest is in the high category. Based on the results of the regression test, there is an influence between the librarian's communication style on visiting visitors' interest. This is shown by the linear regression equation $Y=6.510+0.808 X$ and the $t$ value of 8,985 and the significant value of 0.001. The regression results can be seen that the $t$ value is 8,985 with a significant value of $0,000<0.10$, then Ho is rejected and Ha is accepted.

Conclusions. Based on the research that has been done on the strong relationship between the librarian's communication style and visiting interest. With the librarian's communication style provided, it makes it easy for users to communicate with librarians to meet the information needs needed by the users.
\end{abstract}

Key words: Gaya komunikasi, pustakawan, minat kunjung, pemustaka, perpustakaan perguruan tinggi

\begin{abstract}
ABSTRAK
Pendahuluan. Penelitian ini bertujuan untuk mengetahui apakah gaya komunikasi pustakawan di Perpustajaan Universitas Islam Negeri Sulthan Thaha Saifuddin Jambi berpengaruh terhadap minat kunjung pemustaka. Hal ini didasarkan pada pentingnya komunikasi yang merupakan kebutuhan dasar manusia sebagai makhluk sosial, dan bagian penting dalam perpustakaan, khususnya dalam melayani pengguna.

Metode Penelitian. Penelitian ini menggunakan metode kuantitatif dengan teknik pengumpulan data yang digunakan yaitu angket, observasi, dan dokumentasi. Angket dalam penelitian ini menggunakan skla likert. Populasi penelitian ini yaitu berjumlah 8129 mahasiswa/i yang aktif saja dan sampel yang digunakan sebanyak 99. Teknik sampel penelitian ini menggunakan teknik sampling insidental.

Data Analisis. Adapun teknik analisis data yang digunakan analisis data deskriptif dengan teknik analisis regresi sederhana.untuk mengetahui adaatau tidaknya pengaruh dalam penelitian ini menggunakan uji hipotesis.
\end{abstract}


Hasil dan Pembahasan. Hasil penelitian ini yaitu variabel gaya komunikasi pustakawan diperoleh presentase skor sebesar 78,29\% yang berarti bahwa pengaruh gaya komunikasi pustakawan termasuk dalam kategori sangat tinggi. Variabel minat kunjung diperoleh presentase skor sebesar 80,24\% yang berarti bahwa minat kunjung termasuk dalam kategori tinggi. Berdasarkan hasil uji regresi adanya pengaruh antara gaya komunikasi pustakawan terhadap minat kunjung pemustaka. Hal ini ditunjukan dengan persamaan regresi linear $Y=6.510+0,808 X$ dan nilai $t$ hitung 8.985 serta nilai signifikan hitung 0.001. hasil regresi dapat diketahui nilai t hitung sebesar 8.985 dengan nilai signifikan 0,000 < 0,10, maka Ho ditolak dan Ha diterima.

Kesimpulan dan Saran. Berdasarkan penelitian yang telah dilakukan terhadap hubungan yang kuat antara gaya komunikasi pustakawan dengan minat kunjung. Dengan adanya gaya komunikasi pustakawan yang diberikan, memberikan kemudahan berkomunikasi bagi pemustaka dengan pustakawan untuk memenuhi kebutuhan informasi yang dibutuhkan oleh pemustaka.

Kata Kunci: Gaya komunikasi, pustakawan, minat kunjung, pemustaka, perpustakaan perguruan tinggi

\section{A. PENDAHULUAN}

Pada perpustakaan dan lembaga-lembaga informasi yang ada di dalam struktur masyarakat, pembahasan terpenting adalah pada bagimana pola hubungan antar orang-orang yang ada di dalamnya, pola interaksi antar manusia di dalam dan di luar lingkungannya, aspek dan pesanpesan informasi yang terjadi di dalamnya, serta aspek-aspek lainnya dari pola kehidupan manusia di dalam lembaga atau struktur sosial lainnya. ${ }^{1}$ Gaya komunikasi pustakawan dengan pengguna salah satunya adalah tercapainnya aspek komunikasi efektif pustkawan saat melayani pengguna, karena komunikasi merupakan salah satu kebutuhan dasar manusia sebagai makhluk sosial, dan merupakan bagian penting dalam perpustakaan, khususnya dalam melayani pengguna. ${ }^{2}$ Pustakawan yang ada di perpustakaan, pada realitanya memiliki gaya komunikasi yang berbeda-beda, ada yang banyak berbicara dengan suara yang keras, ramah atau bersahabat, santai, penuh perhatian, ada yang ketika berkomunikasi menimbulkan perselisihan, ada yang menggunakan kata-kata yang indah (dramatis), menggunakan gerakan-gerakan anggota tubuh, terbuka, ada sekali berbicara langsung meninggalkan kesan atau sangat berkesan bagi yang mendengarkannya, serta ada juga seseorang ketika berkomunikasi, bisa dengan mudah mempengaruhi, mengarahkan dan memotivasi pendengarnya atau komunikannya, atau di dalam ilmu perpustakaan disebut dengan pemustaka (user). Sebagaimana yang dikatakan oleh Robert W. Norton dan Loyd S. Pettegrew. yaitu "components communicator style that are dominant, open, dramatic, relaxed, contentious, animated, friendly, attentive, and impression-leaving, and communicator image (komponen gaya komunikator yang dominan, terbuka, dramatis, santai,

\footnotetext{
${ }^{1}$ Sentosa, A. T.pola komunikasi dalam proses interaksi sosial di pondok pesantren nurul islam samarinda. ilmu komunikasi volume 3, nomor 3. 2015

${ }^{2}$ Liliweri, A. Komunikai Serba Ada Serba Makna. (Jakarta: Prenada Media Group.2011). hlm 308
} 
kontroversial, animasi, ramah, penuh perhatian, dan meninggalkan kesan, dan citra komunikator)". Berdasarkan survey awal, minat kunjung pemustaka ke perpustakaan Universitas Islam Negeri Sulthan Thaha Saifuddin Jambi masih rendah. Hal ini terlihat dari jumlah pemustaka yang terdaftar di perpustakaan sebanyak 16.089 orang sedangkan jumlah pemustaka yang aktif 8.129 orang. Dari sini dapat dikatakan bahwa hanya sebagian pemustaka yang aktif mengunjungi perpustakaan. Dan dari bulan September-Desember 2019 atau 1 semester jumlah pengunjung hanya sebanyak 10.382 orang. Artinya dalam 1 semester mahasiswa yang aktif saja hanya 1-2 kali mengunjungi perpustakaan. ${ }^{3}$

\section{B. TINJAUAN PUSTAKA}

\section{Komunikasi}

Komunikasi mengandung makna bersama-sama (common), istilah komunikasi atau communication berasal dari bahasa latin yaitu communicatio yang berarti pemberitahuan atau pertukaran. Kata sifatnya communis yang bermakna umum atau bersama-sama. ${ }^{4}$ Menurut Wilbur Shcram dalam buku Dr. Ir. Ratu Mutialela Caropeboka menyatakan bahwa komunikasi adalah suatu perwujudan persamaan makna antara komunikator dan komunikasi. Tidak hanya tukar pendapat tetapi mencakup lebih luas artinya suatu peroses penyampaian pesan di mana sesorang atau lembaga tersebut berusaha mengubah pendapat atau perilaku si penerima pesan atau penerima informasi. ${ }^{5}$

\section{Gaya komunikasi}

Gaya komunikasi adalah prilaku komunikasi yang dilakukan seseorang dalam suatau organisasi yang bertujuan untuk mendapatkan feedback dari orang lain terhadap pesan organisasional yang disampaikan. ${ }^{6}$ Gaya komunikasi atau communication style akan memberikan pengetahuan kepada kita tentang bagaimana perilaku organisasi ketika mareka melaksanakan tindakan berbagi informasi dan gagasan. Gaya komunikasi atau communication style didefinisikan sebagai seperangkat perilaku antar pribadi yang digunakan dalam situasi tertentu. Masing-masing gaya komunikasi terdiri dari

\footnotetext{
${ }^{3}$ Robert W. Norton dan Loyd S. Pettegrew. Communication Style As An Effect Determinant Of Attraction. Vol. 4. No. 3. University of Michigan. 1977. Hlm. 260-261. Dalam http://deepblue.lib.umich.edu/bitstream/handle/2027.42/66866/10.1177_009365027700400302.pdf?sequence=2. Di akses pada tanggal 30 Oktober 2019. Pukul 08.30. WIB.

${ }^{4}$ Wiryanto. Pengantar Ilmu Perpustakaan. (Jakarta: PT. Gramedia Widiasarana Indonesia. 2004) hlm 5

${ }^{5}$ Dr. Ir. Ratu Mutialela Caropeboka, M. Konsep dan aplikasi ilmu komunikasi. (Yogyakarta: Andi (Anggota IKAPI). 2017) Hlm 3-5

${ }^{6}$ Sendjaja, D. Pengatar Ilmu Komunikasi . (Jakarta: Universitas Terbuka.1996) hlm 7
} 
sekumpulan perilaku komunikasi yang dipakai untuk mendapatkan respons atau tanggapan tertentu pula.

Norton dalam Alo Liliweri mengelompokkan tipe atau kategori gaya komunikasi kedalam sepuluh jenis yaitu sebagai berikut:

a. Gaya dominan (dominant style), gaya seseorang individu untuk mengontrol situasi sosial.

b. Gaya dramatis (dramatic style), gaya seseorang individu yang selalu hidup ketika dia becakap-cakap.

c. Gaya kontraversial (controversial style), gaya seseorang yang selalu berkomunikasi secara argumentatif atau cepat untuk menantang orang lain.

d. Gaya animasi (animated style), gaya seseorang yang berkomunikasi secara aktif dengan memakai bahasa nonverbal.

e. Gaya berkesan (inpression style), gaya berkomunikasi yang merangsang orang lain sehingga mudah diingat, gaya yang sangat mengesankan.

f. Gaya santai (relaxes style), gaya seseorang yang berkomunikkasi dengan tenang dan senang penuh senyum dan tawa.

g. Gaya atentif (attentive style), gaya seseorang yang berkomunikasi dengan memberikan perhatian penuh kepada orang lain, bersikap simpati dan bahkan empeti, mendengarkan orang lain dengan sungguh-sungguh.

h. Gaya terbuka (open style), gaya seseorang yang berkomunikasi secara terbuka yang ditunjukkan dengan tampilan jujur dan mungkin saja blakblakan.

i. Gaya bersahabat (friendly style), gaya komunikasi yang ditampilkan seseorang secara ramah, merasa dekat, selalu memberikan respon positif dan mendukung.

j. Gaya yang tepat (precise style), gaya yang tepat dimana komunikator meminta untuk membicarakan suatu konten yang tepat dan akurat dalam komunikasi lisan. ${ }^{7}$

\section{Minat kunjung}

Dalam Kamus Bahasa Indonesia minat adalah kecenderungan hati yang tinggi terhadap sesuatu. Kunjungan dalam kamus besar bahas aindonesia dapat diartikan sebagai berkunjung, datang atau pergi untuk menengok atau mendatangi. ${ }^{8}$

Tujuan berkunjung yaitu sebagai berikut: ${ }^{9}$

\footnotetext{
${ }^{7}$ Liliweri, A.. Komunikai Serba Ada Serba Makna. (Jakarta: Prenada Media Group.2011) hlm 309-310

${ }^{8}$ Yasyin, S. Kamus Lengkap Bahasa Indonesia . (Surabaya: Amanah. 1999)

${ }^{9}$ Suwarno, W. Psikologi Perpustakaan . (Jakarta: Sagung Seto. 2009)
} 
a. Berkunjung untuk kesenangan. Dalam artian masyarakat datang memanfaatkan koleksi perpustakaan yang disenangi seperti, membaca novel, surat kabar, komik dan lain-lain.

b. Berkunung untuk tujuan memperoleh sesuatu yang baru (ilmu pengetahuan).

c. Berkunjung untuk menyelesaikan tugas atau pekerjaan.

Faktor yang mempengaruhi minat seseorang bisa dipengaruhi oleh bebrapa hal diantara nya minat sebagai berikut: ${ }^{10}$

a. Kondisi fisik, keadaan jasmani dan kondisi yang baik akan mempengaruhi minat yang lebih tinggi.

b. Keadan pisikis, perubahan pisikis seseorang mempengaruhi suatu bidang tertentu.

c. Lingkungan sosial, lingkungan yang ramah atau alam sekitar yang kondusif akan memmpengaruhi minat kunjung dalam waktu yang relatif lama.

d. Rasa ingin tau yang tinggi,seseorang yang minat terhadap sesuatu karena tertarik dan ingin tahu.

\section{METODE PENELITIAN}

\section{Populasi dan Sampel}

Populasi adalah keseluruhan dari subjek penelitian. Jadi yang dimaksud populasi adalah individu yang memiliki sifat yang sama walaupun persentase kesamaan itu sedikit, atau dengan kata lain seluruh individu yang akan dijadikan sebagai objek penelitian. ${ }^{11}$ Populasi yang akan digunakan dalam penelitian ini adalah pemustaka yang aktif di perpustakaan Universitas Islam Negeri Sulthan Thaha Saifuddin Jambi yakni sebanyak 8129 orang. Pengambilan sampel menggunakan teknik sampling accidental, yaitu teknik penentuan sampel berdasarkan faktor kebetulan, yaitu siapa saja yang secara kebetulan bertemu dengan peneliti dapat digunakan sebagai sampel, bila dipandang orang yang kebetulan ditemu itu cocok sebagai sumber data. Metode ini digunakan dengan tujuan agar lebih efktif dari segi waktu dan tetap memberikan kesempatan kepada setiap anggota perpustakaan. Sampel yang diinginkan oleh peneliti dalam penelitian ini adalah anggota perpustakaan Universitas Islam Negeri Sulthan Thaha Saifuddin Jambi dengan tidak

\footnotetext{
${ }^{10}$ Habir. Pengaruh Layanan Perpustakaan terhadap Minat Kunjung Pemustaka di Perpustakaan STIKES Mega Rizky Makassar. Hal. 160

${ }^{11}$ Syofian Siregar. Metode Penelitian Kuantitatif. Hal. 30
} 
memandang Jenis kelamin, Fakultas, Jurusan dan Semester. Dengan rumus Slovin maka banyak sampel adalah:

$$
\begin{aligned}
n & =\frac{\mathrm{N}}{1+N e^{2}} \\
n & =\frac{8129}{1+(8129)(10 \%)^{2}} \\
n & =\frac{8129}{1+81,29} \\
n & =\frac{8129}{82,29} \\
n & =98,7 \text { dibulatkan menjadi } 99
\end{aligned}
$$

\section{Instrumen Penelitian}

Instrumen penelitian merupakan komponen yang sangat penting dalam menjalankan subuah penelitian dalam usaha mendapatkan data. Instrumen penelitian adalah suatu alat yang digunakan mengukur fenomena alam maupun sosial yang diamati. ${ }^{12}$ Untuk memperoleh data tentang “ pengaruh gaya komunikasi pustakawan terhadap minat kunjung di perpustakaan Universitas Islam Negeri Sulthan Thaha Saifuddin Jambi ”, instrumen pengumpulan data yang digunakan berupa angket/kuesioner yang bersekala likert.

Tabel 1. Skala Likert

\begin{tabular}{lc}
\multicolumn{2}{c}{ Pernyataan positif } \\
\hline \multicolumn{1}{c}{ Ungkapkan } & Nilai \\
Sangat setuju & 4 \\
Setuju & 3 \\
Tidak setuju & 2 \\
Sangat tidak setuju & 1 \\
\hline
\end{tabular}

Berikut kisi-kisi instrument penelitian yang disusun peneliti adalah sebagai berikut:

Tabel 2. Kisi - kisi Instrument Penelitian

\begin{tabular}{lllc}
\hline NO & \multicolumn{1}{c}{ Variabel } & \multicolumn{1}{c}{ Indikator variabel } & $\begin{array}{c}\text { Nomor } \\
\text { item }\end{array}$ \\
\hline 1. & Gaya Komunikasi & Dominan (dominant) & 1 \\
& pustakawan & Ramah (friendly) & 2 \\
& (Variabel X) & Penuh perhatian (attentive) & 3 \\
& Santai (relaxed) & 4 \\
& Perdebatan (contentious) & 5 \\
& Dramatis (dramatic) & 6 \\
& Ekspresi (animated) & 8 \\
\hline
\end{tabular}

${ }^{12}$ Irawan, Prasetya. Logika dan Prosedur Penelitian. (Jakarta: STIA-LAN. 1999).hlm 73 


\begin{tabular}{|c|c|c|c|c|}
\hline \multirow{6}{*}{2.} & & \multirow{6}{*}{ Kunjung } & Meninggalkan kesan(impression leaving) & 9 \\
\hline & & & $\begin{array}{l}\text { Citra Komunikasi } \\
\text { image) }\end{array}$ & 10 \\
\hline & Minat & & Kondisi fisik. & 1,2 \\
\hline & Pemustaka & & Kadaan pisikis. & 3,4 \\
\hline & (Variabel Y) & & Lingkungan sosial & 5,6 \\
\hline & & & Rasa ingin tau yang tinggi. & $7,8,9,10$ \\
\hline
\end{tabular}

\section{Analisis Data}

\section{a. Analisis Data Deskriptif}

Data yang sudah terkumpul melalui angket kemudian dianalisis. Analisis data dilakukan dengan menggunakan metode deskriptif dengan cara menyusun dan mengelompokkan data kemudian dianalisis. Data akan ditabulasi sesuai dengan kelompok aspek yang diteliti, untuk memudahkan interprestasi data yang disajikan dalam bentuk tabel kemudian dianalisis dan diinterprestasikan. Untuk menghitung presentasi hasil angket adalah:

$$
P=\frac{F}{n} \times 100 \%
$$

Keterangan:

$\mathrm{P}=$ Presentase

$\mathrm{F}=$ Jumlah jawaban yang diperoleh

$\mathrm{n}=$ Jumlah responden

Setelah didapatkan presentasse jawaban responden selanjutnya diberikan penafsiran atau penilaian terhadap hasil penelitian. Adapun parameter untuk penafsiran menurut Arikunto. $^{13}$

Tabel 3. Pedoman Untuk Nilai Interval

\begin{tabular}{|c|c|c|}
\hline No & $\begin{array}{c}\text { Presentase Batas } \\
\text { Interval }\end{array}$ & Kategori Penilian \\
\hline 1 & $0-20 \%$ & Sangat rendah \\
\hline 2 & $21-40 \%$ & Rendah \\
\hline 3 & $41-60 \%$ & Sedang \\
\hline 4 & $61-80 \%$ & Tinggi \\
\hline 5 & $81-100 \%$ & Sangat tinggi \\
\hline
\end{tabular}

\section{b. Regresi Linier Sederhana}

Teknik analisis data dalam penelitian ini yaitu menggunakan analisis regresi sederhana. Regresi atau peramalan adalah suatu proses memperkirakan secara sistematis tentang apa yang palingmungkin terjadi di masa yang akan datang berdasarkan informasi masa lalu dan

\footnotetext{
${ }^{13}$ S. Arikunto. Prosedur Penelitian Suatu Pendekatan Praktek. hlm. 57.
} 
sekarang yang dimiliki agar kesalahanya dapat diperkecil. Regresi dapat juga diartikan sebagai usaha memperkirakan perubahan. ${ }^{14}$

Persamaan regresi dirumuskan:

$\hat{Y}=a+\mathrm{bX}$

Keterangan

$\widehat{Y}=($ baca Y topi) subjek variabel terkait yang diproyeksikan

$\mathrm{X}=$ variabel bebas ang mempunyai nilai tertentu untuk diperediksikan

$a=$ nilai konstanta harga $\mathrm{Y}$ jika $\mathrm{X}=0$

$b=$ nilai arah sebagai penentu ramalan (prediksi) yang nilai peningkatan $(+)$ atau

nilai penurunan (-) variabel Y

$$
b=\frac{n \cdot \sum X Y-\sum X \cdot \sum Y}{n \cdot \sum X^{2} \cdot\left(\sum X\right)^{2}} \quad a=\frac{\sum Y-b \cdot \sum X}{n}
$$

Anlisis regresi sederhana dapat dihitung dengan menggunakan software SPSS.

\section{c.Uji Hipotesis}

Merupakan hipotesis yang menunjukkan hubungan sederhana sehingga diuji dengan menggunakan teknik korelasi Product Moment. Hubungan yang dicari tersebut berlaku untuk sampel saja sehingga harus dilakukan uji signifikansi yaitu untuk menguji apakah hubungan tersebut berlaku untuk seluruh populasi yang diteliti. Uji signifikansi korelasi Product Moment dilakukan dengan membandingkan antara $\mathrm{R}_{\text {hitung }}$ dengan $\mathrm{R}_{\text {tabel }}$ pada taraf signifikansi 10\%. Apabila $\mathrm{R}_{\text {hitung }}$ lebih besar dari $\mathrm{R}_{\text {tabel }}$ maka hipotesis diterima. Sebaliknya, apabila $\mathrm{R}_{\text {hitung }}$ lebih kecil dari $\mathrm{R}_{\text {tabel }}$ maka hipotesis ditolak.

\section{HASIL DAN PEMBAHASAN}

\section{Analisis Data $X$ (Gaya Komunikasi Pustakawan)}

\section{a. Gaya komunikasi pustakawan}

1) Saya merasa pustakawan memberikan respon yang cepat untuk menjawab pertanyaan atau keluhan pengguna.

Tabel 4. Saya merasa pustakawan memberikan respon yang cepat untuk menjawab pertanyaan atau keluhan pengguna.

\begin{tabular}{l|cccc}
\multicolumn{1}{c}{ Jawaban } & Bobot Nilai & F & P & S \\
\hline Sangat Setuju & 4 & 25 & $25,25 \%$ & $\mathbf{1 0 0}$ \\
Setuju & 3 & 65 & $65,65 \%$ & $\mathbf{1 9 5}$ \\
Tidak Setuju & 2 & 9 & $9,09 \%$ & $\mathbf{1 8}$ \\
Sangat Tidak Setuju & 1 & 0 & 0 & $\mathbf{0}$ \\
Jumlah & & $\mathbf{9 9}$ & $\mathbf{1 0 0 \%}$ & 313
\end{tabular}

\footnotetext{
${ }^{14}$ Simamora, B. (2008). panduan riset prilaku konsumen. Jakarta: Gramedian Pustaka Utama.hlm.147-
} 
Skor Rata-Rata

$313: 396 \times 100=79,04 \%$

Tabel di atas menjelaskan tentang pernyataan pertama. Dapat diketahui bahwa jumlah paling tinggi dari jawaban responden adalah 65 jawaban (65\%) menjawab setuju, sementara untuk jawaban sangat setuju mendapat pilihan sebanyak 25 responden (25\%), untuk jawaban tidak setuju sebanyak 9 responden (9\%) dan tidak ada responden yang menjawab sangat tidak setuju. Hasil skor rata-rata pernyataan pertama pada tabel ini adalah 3,13 dipersentasekan menjadi 79,04. Skor ini didapatkan dari olahan data dengan menggunakan skala likert. Skor ini berada pada skala interval $61-80 \%$. Skala ini menunjukan bahwa gaya komunikasi pustakawan tinggi.

2) Pustakawan memberikan pelayanan pertama dengan baik

Tabel 5. Pustakawan memberikan pelayanan pertama dengan baik

\begin{tabular}{lcccc}
\multicolumn{1}{c}{ Jawaban } & Bobot Nilai & F & P & S \\
\hline Sangat Setuju & 4 & 30 & $30,30 \%$ & $\mathbf{1 2 0}$ \\
Setuju & 3 & 64 & $64,64 \%$ & $\mathbf{1 9 2}$ \\
Tidak Setuju & 2 & 5 & $5,05 \%$ & $\mathbf{1 0}$ \\
Sangat Tidak Setuju & 1 & 0 & 0 & $\mathbf{0}$ \\
Jumlah & & $\mathbf{9 9}$ & $\mathbf{1 0 0 \%}$ & 322 \\
\hline Skor Rata-Rata & & \multicolumn{2}{c}{$322 / 396 \times 100=81,31 \%$}
\end{tabular}

Tabel di atas menjelaskan tentang pernyataan kedua. Dapat diketahui bahwa jumlah paling tinggi dari jawaban responden adalah 64 jawaban (64\%) menjawab setuju, sementara untuk jawaban sangat setuju mendapat pilihan sebanyak 30 responden (30\%), untuk jawaban tidak setuju sebanyak 5 responden (5\%) dan tidak ada responden yang menjawab sangat tidak setuju. Hasil skor rata-rata pernyataan kedua pada tabel ini adalah 3,22 dipresentasikan menjadi $81,31 \%$. Skor ini didapatkan dari olahan data dengan menggunakan skala likert. Skor ini berada pada skala interval $81-100 \%$. Skala ini menunjukan bahwa pelayanan pustakawan sangat tinggi.

3) Gaya komunikasi pustakawan memberikan motivasi untuk memanfaatkan informasi yang ada di perpustakaan.

Tabel 6. Gaya komunikasi pustakawan memberikan motivasi untuk memanfaatkan informasi yang ada di perpustakaan

\begin{tabular}{lcccc}
\multicolumn{1}{c}{ Jawaban } & Bobot Nilai & F & P & S \\
\hline Sangat Setuju & 4 & 25 & $25,25 \%$ & $\mathbf{1 0 0}$ \\
Setuju & 3 & 62 & $62,62 \%$ & $\mathbf{1 8 6}$ \\
Tidak Setuju & 2 & 12 & $12,12 \%$ & $\mathbf{2 4}$ \\
Sangat Tidak Setuju & 1 & 0 & 0 & $\mathbf{0}$
\end{tabular}




\begin{tabular}{lccc} 
Jumlah & 99 & $\mathbf{1 0 0 \%}$ & 310 \\
\hline Skor Rata-Rata & $310 / 396 \times 100=78,28 \%$
\end{tabular}

Pada pernyataan ketiga mengenai pengertian dan pemahaman dengan sub indikator bukti langsung, jawaban responden paling tinggi yaitu setuju sebanyak $62 \%$ atau 62 orang responden yang memilih setuju. Kemudian sangat setuju sebanyak $25 \%$ atau 25 orang responden. Jawaban lainnya tidak setuju sebanyak $12 \%$ atau 12 orang responden dan tidak ada responden yang memilih jawaban sangat tidak setuju. Hasil skor rata-rata pernyataan pertama pada tabel ini adalah 3,13. Skor ini didapatkan dari olahan data dengan menggunakan skala likert. Skor ini berada pada skala interval 2,52 - 3,27. Skala ini menunjukkan bahwa pengaruhnya adalah tinggi.

4) Gaya komunikasi pustakawan menampilkan sikap yang tenang.

Tabel 7. Gaya komunikasi pustakawan menampilkan sikap yang tenang.

\begin{tabular}{lcccc} 
Jawaban & Bobot Nilai & F & P & S \\
\hline Sangat Setuju & 4 & 24 & $24,24 \%$ & $\mathbf{9 6}$ \\
Setuju & 3 & 70 & $70,70 \%$ & $\mathbf{2 1 0}$ \\
Tidak Setuju & 2 & 5 & $5,05 \%$ & $\mathbf{1 0}$ \\
Sangat Tidak & 1 & 0 & 0 & $\mathbf{0}$ \\
Setuju & & & & 316 \\
Jumlah & & $\mathbf{1 0 0}$ & $\mathbf{1 0 0 \%}$ & $316 / 396$ X $100=79,79 \%$
\end{tabular}

Pada pernyataan keempat mengenai pengertian dan pemahaman dengan sub indikator bukti langsung, jawaban responden paling tinggi yaitu setuju sebanyak $70 \%$ atau 70 orang responden yang memilih setuju. Kemudian sangat setuju sebanyak $24 \%$ atau 24 orang responden. Jawaban lainnya tidak setuju sebanyak $5 \%$ atau 5 orang responden dan tidak ada responden yang memilih jawaban sangat tidak setuju. Hasil skor rata-rata pernyataan pertama pada tabel ini adalah 3,16 dipresentasekan menjadi 79,79\%. Skor ini didapatkan dari olahan data dengan menggunakan skala likert. Skor ini berada pada skala interval $61-80 \%$. Skala ini menunjukkan bahwa persepsinya adalah tinggi.

5) Gaya komunikasi pustakawan tidak menimbulkan perdebatan.

Tabel 8. Gaya komunikasi pustakawan tidak menimbulkan perdebatan

\begin{tabular}{|c|c|c|c|c|}
\hline Jawaban & Bobot Nilai & $\mathrm{F}$ & $\mathrm{P}$ & S \\
\hline Sangat Setuju & 4 & 25 & $25,25 \%$ & 100 \\
\hline Setuju & 3 & 64 & $64,64 \%$ & 192 \\
\hline Tidak Setuju & 2 & 8 & $8,08 \%$ & 16 \\
\hline Sangat Tidak Setuju & 1 & 2 & $2,02 \%$ & 2 \\
\hline Jumlah & & 99 & $100 \%$ & 310 \\
\hline
\end{tabular}


Pada pernyataan kelima mengenai penilaian dan evaluasi jawaban yang paling tinggi yaitu setuju sebanyak $64 \%$ atau 64 orang responden. Jawaban sangat setuju sebanyak $25 \%$ atau 25 orang responden. Jawaban lainnya seperti tidak setuju mendapat jawaban sebanyak $8 \%$ atau 8 orang responden dan terakhir jawaban sangat tidak setuju sebanyak $2 \%$ atau 2 orang responden. Hasil skor rata-rata pernyataan pertama pada tabel ini adalah 3,10 dan dipresentasikan menjadi 78,28\%. Skor ini didapatkan dari olahan data dengan menggunakan skala likert. Skor ini berada pada skala interval $61-80 \%$. Skala ini menunjukkan bahwa Tinggi.

6) Gaya komunikasi pustakawan menggunakan kata-kata yang enak di dengar.

Tabel 9. Gaya komunikasi pustakawan menggunakan kata-kata yang enak didengar

\begin{tabular}{lcccc}
\multicolumn{1}{c}{ Jawaban } & Bobot Nilai & F & P & S \\
\hline Sangat Setuju & 4 & 31 & $31,3 \%$ & $\mathbf{1 2 4}$ \\
Setuju & 3 & 59 & $59,5 \%$ & $\mathbf{1 7 7}$ \\
Tidak Setuju & 2 & 9 & $9,09 \%$ & $\mathbf{1 8}$ \\
Sangat Tidak Setuju & 1 & 0 & 0 & $\mathbf{0}$ \\
Jumlah & & $\mathbf{9 9}$ & $\mathbf{1 0 0 \%}$ & 319 \\
\hline Skor Rata-Rata & & \multicolumn{2}{c}{$319 / 396 \times 100=80,55 \%$}
\end{tabular}

Pada pernyataan keenam mengenai pengertian dan pemahaman dengan sub indikator bukti langsung, jawaban responden paling tinggi yaitu setuju sebanyak $59 \%$ atau 59 orang responden yang memilih setuju. Kemudian sangat setuju sebanyak $31 \%$ atau 31 orang responden. Jawaban lainnya tidak setuju sebanyak 9\% atau 9 orang responden dan tidak ada responden yang memilih jawaban sangat tidak setuju. Hasil skor rata-rata pernyataan pertama pada tabel ini adalah 3,19 dan dipresentasikan menjadi 80,55\%. Skor ini didapatkan dari olahan data dengan menggunakan skala likert. Skor ini berada pada skala interval 61-80\%. Skala ini menunjukkan bahwa persepsinya adalah Tinggi.

7) Pustakawan memahami kebutuhan pemustaka

Tabel 10. Pustakawan memahami kebutuhan pemustaka

\begin{tabular}{lcccrr}
\multicolumn{1}{c}{ Jawaban } & Bobot Nilai & F & P & S \\
\hline Sangat Setuju & 4 & 27 & $27,27 \%$ & $\mathbf{1 0 8}$ \\
Setuju & 3 & 63 & $63,63 \%$ & $\mathbf{1 8 9}$ \\
Tidak Setuju & 2 & 9 & $9,09 \%$ & $\mathbf{1 8}$ \\
Sangat Tidak Setuju & 1 & 0 & 0 & $\mathbf{0}$ & \\
Jumlah & & $\mathbf{9 9}$ & $\mathbf{1 0 0 \%}$ & 315 \\
\hline Skor Rata-Rata & & & $315 / 396 \times 100=79,54 \%$
\end{tabular}

Pada pernyataan ketujuh mengenai pengertian dan pemahaman dengan sub indikator bukti langsung, jawaban responden paling tinggi yaitu setuju sebanyak $63 \%$ atau 63 orang responden yang memilih setuju. Kemudian sangat setuju 
sebanyak $27 \%$ atau 27 orang responden. Jawaban lainnya tidak setuju sebanyak 9\% atau 9 orang responden dan responden yang memilih jawaban sangat tidak setuju tidak ada. Hasil skor rata-rata pernyataan pertama pada tabel ini adalah 3,15 dan dipresentasikan menjadi 79,54\%. Skor ini didapatkan dari olahan data dengan menggunakan skala likert. Skor ini berada pada skala interval $61-80 \%$. Skala ini menunjukkan bahwa persepsinya adalah Tinggi.

8) Pustakawan berkenan menyampaikan informasi penting kepada pemustaka. Tabel 11. Pustakawan berkenan menyampaikan informasi penting kepada pemustaka

\begin{tabular}{lcccc}
\multicolumn{1}{c}{ Jawaban } & Bobot Nilai & F & P & \multicolumn{2}{c}{ S } \\
\hline Sangat Setuju & 4 & 30 & $30,30 \%$ & $\mathbf{1 2 0}$ \\
Setuju & 3 & 58 & $58,58 \%$ & $\mathbf{1 1 6}$ \\
Tidak Setuju & 2 & 11 & $11,11 \%$ & $\mathbf{2 2}$ \\
Sangat Tidak Setuju & 1 & 0 & 0 & $\mathbf{0}$ \\
Jumlah & & $\mathbf{9 9}$ & $\mathbf{1 0 0 \%}$ & 258 \\
\hline Skor Rata-Rata & & \multicolumn{3}{c}{$258 / 396$ X $100=65,15 \%$}
\end{tabular}

Pada pernyataan kedelapan mengenai pustakawan menyampaikan informasi penting kepada pemustaka, jawaban responden paling tinggi yaitu setuju sebanyak 58\% atau 58 orang responden yang memilih setuju. Kemudian sangat setuju sebanyak $30 \%$ atau 30 orang responden. Jawaban lainnya tidak setuju sebanyak $11 \%$ atau 11 orang responden dan tidak ada responden yang memilih jawaban sangat tidak setuju. Hasil skor rata-rata pernyataan pertama pada tabel ini adalah 2,58 dipresentasekan menjadi 65,15. Skor ini didapatkan dari olahan data dengan menggunakan skala likert. Skor ini berada pada skala interval 61 $80 \%$. Skala ini menunjukkan bahwa persepsinya adalah Tinggi.

9) Pustakawan berkomunikasi secara terbuka dengan pemustaka.

Tabel 12. Pustakawan berkomunikasi secara terbuka dengan pemustaka

\begin{tabular}{lcccc}
\multicolumn{1}{c}{ Jawaban } & Bobot Nilai & F & P & S \\
\hline Sangat Setuju & 4 & 26 & $26,26 \%$ & $\mathbf{1 0 4}$ \\
Setuju & 3 & 60 & $60,60 \%$ & $\mathbf{1 8 0}$ \\
Tidak Setuju & 2 & 13 & $13,13 \%$ & $\mathbf{2 6}$ \\
Sangat Tidak Setuju & 1 & 0 & 0 & $\mathbf{0}$ \\
\multicolumn{1}{c}{ Jumlah } & & $\mathbf{9 9}$ & $\mathbf{1 0 0 \%}$ & 310 \\
\hline Skor Rata-Rata & & \multicolumn{3}{c}{$310 / 396 \times 100=78,28 \%$}
\end{tabular}

Pada pernyataan kesembilan mengenai pengertian dan pemahaman dengan sub indikator bukti langsung, jawaban responden paling tinggi yaitu setuju sebanyak $60 \%$ atau 60 orang responden yang memilih setuju. Kemudian sangat setuju sebanyak $26 \%$ atau 26 orang responden. Jawaban lainnya tidak setuju sebanyak 
$13 \%$ atau 13 orang responden dan responden yang memilih jawaban sangat tidak setuju tidak ada. Hasil skor rata-rata pernyataan pertama pada tabel ini adalah 3,10 dipresentasekan menjadi 78,28. Skor ini didapatkan dari olahan data dengan menggunakan skala likert. Skor ini berada pada skala interval $61-80 \%$. Skala ini menunjukkan bahwa persepsinya adalah Tinggi.

10) Komunikasi pustakawan menunjukan citra yang baik.

Tabel 13. Komunikasi pustakawan menunjukan citra yang baik

\begin{tabular}{lcccr}
\multicolumn{1}{c}{ Jawaban } & Bobot Nilai & F & P & S \\
Sangat Setuju & 4 & 35 & $35,35 \%$ & $\mathbf{1 4 0}$ \\
Setuju & 3 & 57 & $57,57 \%$ & $\mathbf{1 7 1}$ \\
Tidak Setuju & 2 & 7 & $7,07 \%$ & $\mathbf{1 4}$ \\
Sangat Tidak Setuju & 1 & 0 & 0 & $\mathbf{0}$ \\
Jumlah & & $\mathbf{9 9}$ & $\mathbf{1 0 0 \%}$ & 325 \\
\hline Skor Rata-Rata & & \multicolumn{2}{c}{$325 / 396$ X $100=82,07 \%$} &
\end{tabular}

Pada pernyataan kesepuluh mengenai pengertian dan pemahaman dari komunikasi pustakawan menunjukan citra yang baik, jawaban responden paling tinggi yaitu setuju sebanyak $57 \%$ atau 57 orang responden yang memilih setuju. Kemudian sangat setuju sebanyak $35 \%$ atau 35 orang responden. Jawaban lainnya tidak setuju sebanyak $7 \%$ atau 7 orang responden dan tidak ada responden yang memilih jawaban sangat tidak setuju. Hasil skor rata-rata pernyataan pertama pada tabel ini adalah 3,25 di presentasekan menjadi $82,07 \%$. Skor ini didapatkan dari olahan data dengan menggunakan skala likert. Skor ini berada pada skala interval $81-100 \%$. Skala ini menunjukkan bahwa komunikasi pustakawan menunjukan citra yang baik adalah Sangat tinggi.

11) Sekor rata-rata pada gaya komunikasi

Tabel 14. Skor rata-rata pada gaya komunikasi

\begin{tabular}{|c|c|c|c|}
\hline No & Pernyataan & Jawaban & Skor \\
\hline 1 & $\begin{array}{l}\text { Saya merasa pustakawan memberikan respon yang cepat untuk } \\
\text { menjawab pertanyaan atau keluhan pengguna. }\end{array}$ & Tinggi & $79,04 \%$ \\
\hline 2 & Pustakawan memeberikan pelayanana pertama dengan baik. & $\begin{array}{l}\text { Sangat } \\
\text { tinggi }\end{array}$ & $\mathbf{8 1 , 3 1 \%}$ \\
\hline 3 & $\begin{array}{l}\text { Gaya komunikasi pustakawan memberikan montivasi untuk } \\
\text { memanfaatkan informasi yang ada di perpustakaan. }\end{array}$ & Tinggi & $78,28 \%$ \\
\hline 4 & $\begin{array}{l}\text { Gaya komunikasi pustakawan menampilkan gaya komunikasi yang } \\
\text { tenang. }\end{array}$ & Tinggi & $\mathbf{7 9 , 7 9 \%}$ \\
\hline 5 & Gaya komunikasi pustakawan tidak menimbulkan perdebatan. & Tinggi & $78,28 \%$ \\
\hline 6 & $\begin{array}{l}\text { Gaya komunikasi pustakawan menggunakan kata-kata yang enak } \\
\text { didengar. }\end{array}$ & Tinggi & $80,55 \%$ \\
\hline 7 & Pustakawan memahami kebutuhan pemustaka. & Tinggi & $\mathbf{7 9 , 5 4 \%}$ \\
\hline 8 & $\begin{array}{l}\text { Pustakawan berkenan menyampaikan informasi penting kepada } \\
\text { pemustaka }\end{array}$ & Tinggi & $65,15 \%$ \\
\hline 9 & Pustakawan berkomunikasi secara terbuka dengan pemustaka. & Tinggi & $78,28 \%$ \\
\hline 10 & Komunikasi pustakawan menunjukan citra yang baik. & Tinggi & $82,07 \%$ \\
\hline
\end{tabular}

Jumlah $=782,29: 10=78,229$ 
Pengaruh gaya komunikasi pustakawan terhadap minata kunjung pemustaka dalam gaya komunikasi pustakawan adalah Tinggi. Berdasarkan tabel di atas dapat diketahui hasil skor rata- rata yaitu $78,29 \%$. Skor ini berada pada titik 61-80\%. Dengan demikian dapat disimpulkan pengaruh gaya komunikasi pustakawan terhadap minat kunjung pemustaka adalah Tinggi.

\section{b. Minat kunjung pemustaka}

Perpustakaan akan dikatakan berhasil jika pemustakanya memiliki minat kunjung dan kesadaran yang tinggi terhadap manfaat yang akan diperoleh jika berkunjung di perpustakaan. Dalam variabel (Y) minat kunjung terdapat 10 pernyataan. Selanjutnya akan diuraikan secara rinci minat kunjung di Perpustakaan Universitas Islam Negeri Sulthan Thaha Saifuddin Jambi sebagai berikut:

1) Koleksi perpustakaan yang tertata rapi membuat ruang perpustakaan menjadi nyaman.

Tabel 15. Koleksi perpustakaan yang tertata rapi membuat ruang perpustakaa menjadi nyaman.

\begin{tabular}{lllcc}
\multicolumn{1}{c}{ Jawaban } & Bobot Nilai & F & P & S \\
\hline Sangat Setuju & 4 & 38 & $38,38 \%$ & $\mathbf{1 5 2}$ \\
Setuju & 3 & 48 & $48,48 \%$ & $\mathbf{1 4 4}$ \\
Tidak Setuju & 2 & 13 & $13,13 \%$ & $\mathbf{2 6}$ \\
Sangat Tidak Setuju & 1 & 0 & 0 & $\mathbf{0}$ \\
Jumlah & & $\mathbf{9 9}$ & $\mathbf{1 0 0 \%}$ & 322 \\
\hline Skor Rata-Rata & & \multicolumn{3}{c}{$322 / 396 \times 100=81,31 \%$}
\end{tabular}

Tabel di atas menjelaskan tentang pernyataan kesebelas yaitu koleksi perpustakaan yang tertata rapi. Dapat diketahui bahwa jumlah paling tinggi dari jawaban responden adalah 48 jawaban (48\%) menjawab setuju, sementara untuk jawaban sangat setuju mendapat pilihan sebanyak 38 responden $(38 \%)$, untuk jawaban tidak setuju sebanyak 13 responden (13\%) dan yang menjawab sangat tidak setuju tidak ada. Hasil skor rata-rata pernyataan pertama pada tabel ini adalah 3,22 dipresentasekan menjadi 81,31\%. Skor ini didapatkan dari olahan data dengan menggunakan skala likert. Skor ini berada pada skala interval 81 $100 \%$. Skala ini menunjukkan bahwa pengaruh terhadap koleksi perpustakaan yang tertata rapi adalah Sangat tinggi. 
2) Fasilitas yang lengkap membuat saya rajin berkunjung ke perpustakaan.

Tabel 16. Fasilitas yang lengkap membuat saya rajin berkunjung ke perpustakaan

\begin{tabular}{lcccc}
\multicolumn{1}{c}{ Jawaban } & Bobot Nilai & F & P & S \\
\hline Sangat Setuju & 4 & 38 & $38,38 \%$ & $\mathbf{1 5 2}$ \\
Setuju & 3 & 41 & $41,41 \%$ & $\mathbf{1 2 3}$ \\
Tidak Setuju & 2 & 19 & $19,19 \%$ & $\mathbf{3 8}$ \\
Sangat Tidak Setuju & 1 & 1 & $1,01 \%$ & $\mathbf{1}$ \\
Jumlah & \multicolumn{2}{c}{$314 / 396 \times 100=79,29 \%$} &
\end{tabular}

Tabel di atas menjelaskan tentang pernyataan kedua belas yaitu fasilitas yang lengkap. Dapat diketahui bahwa jumlah paling tinggi dari jawaban responden adalah 41 jawaban (41\%) menjawab setuju, sementara untuk jawaban sangat setuju mendapat pilihan sebanyak 38 responden (38\%), untuk jawaban tidak setuju sebanyak 19 responden (19\%) dan yang menjawab sangat tidak setuju sebanyak 1 responden (1\%). Hasil skor rata-rata pernyataan pertama pada tabel ini adalah 3,14 di presentasekan menjadi 79,29\%. Skor ini didapatkan dari olahan data dengan menggunakan skala likert. Skor ini berada pada skala interval $61-80 \%$. Skala ini menunjukkan bahwa fasilitas yang lengkap memiliki hasil yang Tinggi.

3) Saya menemukan pengalaman baru setelah berkunjung ke perpustakaan.

Tabel 17. Saya menemukan pengalaman baru setelah berkunjung ke perpustakaan.

\begin{tabular}{lcccc}
\multicolumn{1}{c}{ Jawaban } & Bobot Nilai & F & P & S \\
Sangat Setuju & 4 & 26 & $26,26 \%$ & $\mathbf{1 0 4}$ \\
Setuju & 3 & 59 & $59,59 \%$ & $\mathbf{1 7 7}$ \\
Tidak Setuju & 2 & 13 & $13,13 \%$ & $\mathbf{2 6}$ \\
Sangat Tidak Setuju & 1 & 1 & $1,01 \%$ & $\mathbf{1}$ \\
Jumlah & & $\mathbf{9 9}$ & $\mathbf{1 0 0 \%}$ & 308 \\
\hline Skor Rata-Rata & & \multicolumn{2}{c}{$308 / 396 \times 100=77,77 \%$}
\end{tabular}

Tabel di atas menjelaskan tentang pernyataan ketigabelas yaitu pengalaman yang baru setelah berkunjung ke perpustakaan . Dapat diketahui bahwa jumlah paling tinggi dari jawaban responden adalah 59 jawaban (59\%) menjawab setuju, sementara untuk jawaban sangat setuju mendapat pilihan sebanyak 26 responden (26\%), untuk jawaban tidak setuju sebanyak 13 responden (13\%) dan yang menjawab sangat tidak setuju sebanyak 1 responden atau (1\%). Hasil skor ratarata pernyataan pertama pada tabel ini adalah 3,08 dipresentasekan menjadi $77,77 \%$. Skor ini didapatkan dari olahan data dengan menggunakan skala likert. 
Skor ini berada pada skala interval 61 - 80\%. Skala ini menunjukkan bahwa saya menemukan pengalaman baru setelah berkunjung ke perpustakaan memiliki hasil yang Tinggi.

4) Saya berkunjung ke perpustakaan karena koleksi perpustakaan memberikan saya informasi yang saya butuhkan

Tabel 18. Saya berkunjung ke perpustakaan karena koleksi perpustakaan memberikan saya informasi yang saya butuhkan

\begin{tabular}{lcccc}
\multicolumn{1}{c}{ Jawaban } & Bobot Nilai & F & P & S \\
Sangat Setuju & 4 & 30 & $30,30 \%$ & $\mathbf{1 2 0}$ \\
Setuju & 3 & 64 & $64,64 \%$ & $\mathbf{1 9 2}$ \\
Tidak Setuju & 2 & 5 & $5,05 \%$ & $\mathbf{1 0}$ \\
Sangat Tidak Setuju & 1 & 0 & 0 & $\mathbf{0}$ \\
Jumlah & \multicolumn{4}{c}{$322 / 396 \times 100=81,31 \%$}
\end{tabular}

Tabel di atas menjelaskan tentang pernyataan keempatbelas yaitu berkunjung ke perpustakaan karena koleksi perpustakaan yang dibutuhkan. Dapat diketahui bahwa jumlah paling tinggi dari jawaban responden adalah 64 jawaban (64\%) menjawab setuju, sementara untuk jawaban sangat setuju mendapat pilihan sebanyak 30 responden (30\%), untuk jawaban tidak setuju sebanyak 5 responden (5\%) dan tidak ada yang menjawab sangat tidak setuju . Hasil skor rata-rata pernyataan pertama pada tabel ini adalah 3,22 dipresentasekan menjadi 81,31\%. Skor ini didapatkan dari olahan data dengan menggunakan skala likert. Skor ini berada pada skala interval $81-100 \%$. Skala ini menunjukkan bahwa memiliki hasil yang Sangat Tinggi.

5) Sikap pustakawan yang ramah memebuat saya rajin berkunjung keperpustakaan.

Tabel 19. Sikap pustkawan yang ramah memebuat saya rajin berkunjung keperpustakaan.

\begin{tabular}{lcccc}
\multicolumn{1}{c}{ Jawaban } & Bobot Nilai & F & P & S \\
\hline Sangat Setuju & 4 & 25 & $25,25 \%$ & $\mathbf{1 0 0}$ \\
Setuju & 3 & 65 & $65,65 \%$ & $\mathbf{1 9 5}$ \\
Tidak Setuju & 2 & 8 & $8,08 \%$ & $\mathbf{1 6}$ \\
Sangat Tidak Setuju & 1 & 1 & $1,01 \%$ & $\mathbf{1}$ \\
Jumlah & & $\mathbf{9 9}$ & $\mathbf{1 0 0 \%}$ & 312 \\
\hline Skor Rata-Rata & \multicolumn{2}{c}{$312 / 396 \times 100=78,78 \%$}
\end{tabular}

Tabel di atas menjelaskan tentang pernyataan kelimabelas yaitu pustakawan yang ramah. Dapat diketahui bahwa jumlah paling tinggi dari jawaban responden adalah 65 jawaban (65\%) menjawab setuju, sementara untuk jawaban sangat setuju mendapat pilihan sebanyak 25 responden (25\%), untuk jawaban tidak setuju sebanyak 8 responden $(8 \%)$ dan yang menjawab sangat tidak setuju 
sebanyak 1 responden (1\%). Hasil skor rata-rata pernyataan pertama pada tabel ini adalah 3,12 dipresentasekan menjadi 78,78\%. Skor ini didapatkan dari olahan data dengan menggunakan skala likert. Skor ini berada pada skala interval 61$80 \%$. Skala ini menunjukkan bahwa memiliki hasil yang Tinggi.

6) Sikap pustakawan yang cepat dan tepat dalam melayani memebuat saya rajin berkunjung keperpustakaan.

Tabel 20. Sikap pustakawan yang cepat dan tepat dalam melayani membuat saya rajin berkunjung keperpustakaan

\begin{tabular}{lcccc}
\multicolumn{1}{c}{ Jawaban } & Bobot Nilai & F & P & S \\
\hline Sangat Setuju & 4 & 29 & $29,29 \%$ & $\mathbf{1 1 6}$ \\
Setuju & 3 & 60 & $60,60 \%$ & $\mathbf{1 8 0}$ \\
Tidak Setuju & 2 & 10 & $10,10 \%$ & $\mathbf{2 0}$ \\
Sangat Tidak Setuju & 1 & 0 & 0 & $\mathbf{0}$ \\
Jumlah & & $\mathbf{9 9}$ & $\mathbf{1 0 0 \%}$ & 316 \\
\hline Skor Rata-Rata & & \multicolumn{2}{c}{$316 / 396 \times 100=79,79 \%$}
\end{tabular}

Tabel di atas menjelaskan tentang pernyataan kelimabelas yaitu pustakawan yang cepat dan tepat dalam melayani . Dapat diketahui bahwa jumlah paling tinggi dari jawaban responden adalah 60 jawaban (60\%) menjawab setuju, sementara untuk jawaban sangat setuju mendapat pilihan sebanyak 29 responden (29\%), untuk jawaban tidak setuju sebanyak 10 responden (10\%) dan tidak ada yang menjawab sangat tidak setuju. Hasil skor rata-rata pernyataan pertama pada tabel ini adalah 3,16 dan di presentasekan menjadi 79,79\%. Skor ini didapatkan dari olahan data dengan menggunakan skala likert. Skor ini berada pada skala interval $61-80 \%$. Skala ini menunjukkan bahwa pustakawan yang cepat dan tepat dalam melayani memiliki hasil yang Tinggi.

7) Koleksi yang banyak memebuat saya tertarik untuk berkunjung ke perpustakaan.

Tabel 21. Koleksi yang banyak memebuat saya tertarik untuk berkunjung ke perpustakaan

\begin{tabular}{lcccc}
\multicolumn{1}{c}{ Jawaban } & Bobot Nilai & F & P & S \\
\hline Sangat Setuju & 4 & 31 & $31,31 \%$ & $\mathbf{1 2 4}$ \\
Setuju & 3 & 49 & $49,49 \%$ & $\mathbf{1 4 7}$ \\
Tidak Setuju & 2 & 17 & $17,17 \%$ & $\mathbf{3 4}$ \\
Sangat Tidak Setuju & 1 & 2 & $2,02 \%$ & $\mathbf{2}$ \\
Jumlah & & $\mathbf{9 9}$ & $\mathbf{1 0 0 \%}$ & 307 \\
\hline Skor Rata-Rata & & \multicolumn{2}{c}{$307 / 396 \times 100=77,52 \%$}
\end{tabular}

Tabel di atas menjelaskan tentang pernyataan ketujuh belas yaitu koleksi yang banyak. Dapat diketahui bahwa jumlah paling tinggi dari jawaban responden adalah 49 jawaban (49\%) menjawab setuju, sementara untuk jawaban sangat 
setuju mendapat pilihan sebanyak 31 responden (31\%), untuk jawaban tidak setuju sebanyak 17 responden (17\%) dan yang menjawab sangat tidak setuju sebanyak 2 responden (2\%). Hasil skor rata-rata pernyataan pertama pada tabel ini adalah 3,07 dipresentasekan menjadi 77,52\%. Skor ini didapatkan dari olahan data dengan menggunakan skala likert. Skor ini berada pada skala interval 61 $80 \%$. Skala ini menunjukkan bahwa pustakawan yang cepat dan tepat dalam melayani memiliki hasil yang Tinggi.

8) Saya berkunjung ke perpustakaan karena koleksi perpustakaan bisa menambah ilmu pengetahuan.

Tabel 22. Saya berkunjung ke perpustakaan karena koleksi perpustakaan bisa menambah ilmu pengetahuan.

\begin{tabular}{lcccc}
\multicolumn{1}{c}{ Jawaban } & Bobot Nilai & F & P & S \\
\hline Sangat Setuju & 4 & 39 & $39,39 \%$ & $\mathbf{1 5 6}$ \\
Setuju & 3 & 57 & $57,57 \%$ & $\mathbf{1 7 1}$ \\
Tidak Setuju & 2 & 3 & $3,03 \%$ & $\mathbf{6}$ \\
Sangat Tidak Setuju & 1 & 0 & 0 & $\mathbf{0}$ \\
Jumlah & & $\mathbf{9 9}$ & $\mathbf{1 0 0 \%}$ & 333 \\
\hline Skor Rata-Rata & \multicolumn{2}{c}{$333 / 396 \times 100=84,09 \%$} &
\end{tabular}

Tabel di atas menjelaskan tentang pernyataan kedelapan belas yaitu berkunjung ke perpustakaan karena koleksi perpustakaan bisa menambah ilmu pengetahuan. Dapat diketahui bahwa jumlah paling tinggi dari jawaban responden adalah 57 jawaban (57\%) menjawab setuju, sementara untuk jawaban sangat setuju mendapat pilihan sebanyak 39 responden (39\%), untuk jawaban tidak setuju sebanyak 3 responden (3\%) dan tidak ada responden yang menjawab sangat tidak setuju. Hasil skor rata-rata pernyataan pertama pada tabel ini adalah 3,33 di presentasekan menjadi $84.09 \%$. Skor ini didapatkan dari olahan data dengan menggunakan skala likert. Skor ini berada pada skala interval $81-100 \%$. Skala ini menunjukkan bahwa berkunjung ke perpustakaan karena koleksi perpustakaan bisa menambah ilmu pengetahuan memiliki hasil yang Sangat tinggi.

9) Saya berkunjung keperpustakaan untuk menambah wawasan dan pengetahuan.

Tabel 23. Saya berkunjung keperpustakaan untuk menambah wawasan dan pengetahuan

\begin{tabular}{ccccc} 
Jawaban & Bobot Nilai & F & P & S \\
\hline Sangat Setuju & 4 & 42 & $42,42 \%$ & $\mathbf{1 6 8}$ \\
Setuju & 3 & 54 & $54,54 \%$ & $\mathbf{1 6 2}$ \\
Tidak Setuju & 2 & 3 & $3,03 \%$ & $\mathbf{6}$ \\
Sangat Tidak Setuju & 1 & 0 & 0 & $\mathbf{0}$ \\
Jumlah & & $\mathbf{9 9}$ & $\mathbf{1 0 0 \%}$ & 336 \\
\hline Skor Rata-Rata & & & $336 / 396 \times 100=84,84 \%$
\end{tabular}


Tabel di atas menjelaskan tentang pernyataan kesembilan belas yaitu berkunjung keperpustakaan untuk menambah wawasan dan pengetahuan. Dapat diketahui bahwa jumlah paling tinggi dari jawaban responden adalah 54 jawaban (54\%) menjawab setuju, sementara untuk jawaban sangat setuju mendapat pilihan sebanyak 42 responden (42\%), untuk jawaban tidak setuju sebanyak 3 responden (3\%) dan tidak ada responden yang menjawab sangat tidak setuju. Hasil skor rata-rata pernyataan pertama pada tabel ini adalah 3,36 dan di presentasekan menjadi $84,84 \%$. Skor ini didapatkan dari olahan data dengan menggunakan skala likert. Skor ini berada pada skala interval 81-100\%. Skala ini menunjukkan bahwa berkunjung keperpustakaan untuk menambah wawasan dan pengetahuan memiliki hasil yang Sangat tinggi.

10) Koleksi yang sesuai dengan kebutuhan membuat saya rajin berkunjung ke perpustakaan.

Tabel 24. Koleksi yang sesuai dengan kebutuhan membuat saya rajin berkunjung ke perpustakaan

\begin{tabular}{lcccc}
\multicolumn{1}{c}{ Jawaban } & Bobot Nilai & F & P & S \\
\hline Sangat Setuju & 4 & 32 & $32,32 \%$ & $\mathbf{1 2 8}$ \\
Setuju & 3 & 49 & $49,49 \%$ & $\mathbf{1 4 7}$ \\
Tidak Setuju & 2 & 15 & $15,15 \%$ & $\mathbf{3 0}$ \\
Sangat Tidak Setuju & 1 & 3 & $3,03 \%$ & $\mathbf{3}$ \\
Jumlah & & $\mathbf{9 9}$ & $\mathbf{1 0 0 \%}$ & 308 \\
\hline Skor Rata-Rata & \multicolumn{4}{c}{$308 / 396 \times 100=77,77 \%$}
\end{tabular}

Tabel di atas menjelaskan tentang pernyataan keduapuluh yaitu Koleksi yang sesuai dengan kebutuhan. Dapat diketahui bahwa jumlah paling tinggi dari jawaban responden adalah 49 jawaban (49\%) menjawab setuju, sementara untuk jawaban sangat setuju mendapat pilihan sebanyak 32 responden (32\%), untuk jawaban tidak setuju sebanyak 15 responden (15\%) dan responden yang menjawab sangat tidak setuju sebanyak 3 atau (3\%). Hasil skor rata-rata pernyataan pertama pada tabel ini adalah 3,08 di presentasekan menjadi $77,77 \%$. Skor ini didapatkan dari olahan data dengan menggunakan skala likert. Skor ini berada pada skala interval 62-80\%. Skala ini menunjukkan bahwa memiliki hasil yang Tinggi.

11) Skor Rata-Rata Minat Kunjung

Tabel 25. Skor Rata-Rata Minat Kunjung

\begin{tabular}{clcc} 
No & \multicolumn{1}{c}{ Pernyataan } & Jawaban & Skor \\
\hline $\mathbf{1}$ & $\begin{array}{l}\text { Koleksi perpustakaan yang tertata rapi membuat ruang } \\
\text { perpustakaan menjadi nyaman. }\end{array}$ & Sangat tinggi & $\mathbf{8 1 , 3 1}$ \\
& & $\mathbf{\%}$
\end{tabular}


2 Fasilitas yang lengkap membuat saya rajin berkunjung ke perpustakaan.

Saya menemukan pengalaman baru setelah saya

3 berkunjung ke perpustakaan.

4 Saya berkunjung ke perpustakaan karena koleksi perpustakaan memberikan saya informasi yang saya butuhkan.

5 Sikap pustakawan yang ramah membuat saya rajin berkunjung ke perpustakaan.

6 Sikap pustakawan yang cepat dan tepat dalam melayani membuat saya rajin berkunjung ke perpustakaan.

7 Koleksi yang banyak membuat saya tertarik untuk berkunjung ke perpustakaan.

8 Saya berkunjung ke perpustakaan karena koleksi perpustakaan bisa menambah ilmu pengetahuan.

9 Saya berkunjung ke perpustakaan untuk menambah wawasan dan pengetahuan.

10 Koleksi yang sesuai dengan kebutuhan membuat saya rajin berkunjung ke perpustakaan.

$\begin{array}{cc}\text { Tinggi } & \mathbf{7 9 , 2 9} \\ & \mathbf{\%} \\ \text { Tinggi } & \mathbf{7 7 , 7 7} \\ & \mathbf{\%} \\ \text { Sangat tinggi } & \mathbf{8 1 , 3 1} \\ & \mathbf{\%} \\ & \mathbf{7 8 , 7 8} \\ \text { Tinggi } & \mathbf{\%} \\ & \mathbf{7 9 , 7 9} \\ \text { Tinggi } & \mathbf{\%} \\ & \mathbf{7 7 , 5 2} \\ \text { Tinggi } & \mathbf{\%} \\ & \mathbf{8 4 , 0 9} \\ \text { Sangat tinggi } & \mathbf{\%} \\ & \mathbf{8 4 , 8 4} \\ \text { Sangat tinggi } & \mathbf{\%} \\ & \mathbf{7 7 , 7 7} \\ \text { Tinggi } & \mathbf{\%} \\ & \end{array}$

Jumlah $=802,47: 10=80,24 \%$

Berdasarkan tabel di atas dapat diketahui hasil skor rata- rata yaitu 80,24\%. Skor ini berada pada titik 61-80\%. Dengan demikian dapat disimpulkan pengaruh gaya komunikasi pustakawan terhadap minat kunjung pemustaka adalah Tinggi. Penelitian ini penelitian menggunakan Uji koleration product moment.

\section{Uji Regresi Linier Sederhana}

Untuk uji regresi linier sederhana ini peneliti menggunakan aplikasi SPSS, adapun hasilnya sebagai berikut:

Tabel 26. Uji Koefisien Determinasi

Model Summary

\begin{tabular}{|l|r|r|r|r|}
\hline Model & R & R Square & Adjusted R Square & $\begin{array}{c}\text { Std. Error of the } \\
\text { Estimate }\end{array}$ \\
\hline 1 & $.674^{\mathrm{a}}$ & .454 & .449 & 3.498 \\
\hline
\end{tabular}

a. Predictors: (Constant), Gaya Komunikasi Pustakawan

b. Dependent Variable: Minat Kunjung Pemustaka

Tabel 27. Koefisien Regresi Sederhana

\begin{tabular}{|c|c|c|c|c|c|c|}
\hline \multicolumn{7}{|c|}{ Coefficients $^{a}$} \\
\hline \multirow{2}{*}{\multicolumn{2}{|c|}{ Model }} & \multicolumn{2}{|c|}{$\begin{array}{l}\text { Unstandardized } \\
\text { Coefficients }\end{array}$} & $\begin{array}{c}\text { Standardize } \\
\mathrm{d}\end{array}$ & \multirow[t]{2}{*}{$\mathrm{t}$} & \multirow[t]{2}{*}{ Sig. } \\
\hline & & B & Std. Error & Beta & & \\
\hline 1 & (Constant) & 6.510 & 2.869 & & 2.269 & .025 \\
\hline
\end{tabular}




\begin{tabular}{|l|l|r|r|r|r|r|}
\hline $\begin{array}{l}\text { Gaya Komunikasi } \\
\text { Pustakawan }\end{array}$ & .808 & .090 & .674 & 8.985 & .001 \\
\hline
\end{tabular}

Dari tabel diatas diperoleh nilai koefisien determinasi $\left(\mathrm{R}^{2}\right)$ sebesar 0,454 . Pada tabel diatas dapat diketahui nilai constant yaitu 6.510 dan nilai gaya komunikasi pustakawan yaitu 0,808. Dari tabel tersebut dapat memperoleh persamaan regresi sebagai berikut:

$\mathrm{Y}=6.510+0,808 \mathrm{X}$

Konstanta $\mathrm{a}=6.510$

Hasil regreasi diatas menunjukan bahwa apabila variabel gaya komunikasi pustakawan ada peningkatan maka minat kunjung pemustaka akan tetap sebesar 6.510 dan apabila variabel gaya komunikasi mengalami kenaikan sebesar $1 \%$ maka menyebabkan kenaikan minat kunjung sebesar 0,808.sedangkan jika dilihat dari nilai koefisien determinasi $\left(\mathrm{R}^{2}\right)$ sebesar 0,454 yang menujukkan bahwa pengaruh variabel gaya komunikasi pustakawan terhadap variabel minat kunjung pemustaka adalah sebesar $45 \%$ sedengkan sisanya dipengaruhi oleh variabel lain di luar penelitian.

\section{Uji Hipotesis}

Uji hipotesis dalam penelitian ini bertujuan untuk mengetahui yang diajukan diterima atau ditolak. Peneliti melakukan uji hipotesis dengan melakukan uji signifikan, yaitu dengan membandingkan uji t dan thitung dengan taraf signifikan 0,01 (10\%). Berdasarkan hasil uji hipotesis dengan menggunakan SPSS for Windows versi sebagai berikut:

Tabel 28. Uji Hipotesis

\begin{tabular}{|c|c|c|c|c|c|c|}
\hline \multicolumn{7}{|c|}{ Coefficients $^{\mathrm{a}}$} \\
\hline \multirow{2}{*}{\multicolumn{2}{|c|}{ Model }} & \multicolumn{2}{|c|}{$\begin{array}{c}\text { Unstandardized } \\
\text { Coefficients }\end{array}$} & \multirow{2}{*}{$\begin{array}{c}\text { Standardized } \\
\text { Coefficients } \\
\text { Beta } \\
\end{array}$} & \multirow[t]{2}{*}{$\mathrm{T}$} & \multirow[t]{2}{*}{ Sig. } \\
\hline & & $\mathrm{B}$ & Std. Error & & & \\
\hline \multirow[b]{2}{*}{1} & (Constant) & 6.510 & 2.869 & & 2.269 & .025 \\
\hline & $\begin{array}{l}\text { Gaya Komunikasi } \\
\text { Pustakawan }\end{array}$ & .808 & .090 & .674 & 8.985 & .000 \\
\hline
\end{tabular}

Dari tabel diatas dapat dinyatakan bahwa t hitung sebesar 8.985 dengan menggunakan $n=99$ dan nilai signifikan 0,01 (10\%) diperoleh nilai $\mathrm{dk}=\mathrm{n}-2=99-2=97$, maka tabel $\mathrm{t}$ tabel 2,660 berarti ini menunjukkan data yang di peroleh $t$ hitung lebih besar dari pada $t$ tabel berarti ini menunjukkan HO ditolak dan Ha diterima. 


\section{E. KESIMPULAN}

Berdasarkan analisis presentase skor pada variabel gaya komunikasi yang terdiri dari dominan, ramah, penuh perhatian, santai, perdebatan,dramatis, ekspresi, terbuka, meninggalkan kesan, dan citra komunikasi diperoleh presentase skor sebesar 78,29\% berada pada interval 61-80\% yang berarti bahwa gaya komunikasi termasuk dalam kategori tinggi. Berdasarkan analisis presentase skor pada variabel minat kunjung yang terdiri dari kondisi fisik, keadaan fisikis, lingkungan sosial, dan rasa ingin tahu yang tinggi. artinya keamanan dan kenyamanan harus diutamakan, tersedianya kebutuhan yang diinginkan dan berprinsip bahwa berkunjung ke perpustakaan merupakan gaya hidup diperoleh presentase skor sebesar $80,24 \%$ berada pada interval $61-80 \%$ yang berarti bahwa minat kunjung termasuk dalam kategori tinggi. Berdasarkan hasil uji regresi adanya pengaruh antara gaya komunikasi pustakawan terhadap minat kunjung pemustaka. Hal ini ditunjukan dengan persamaan regresi linear $\mathrm{Y}=6.510+0,808 \mathrm{X}$ dan nilai t hitung 8.985 serta nilai signifikan hitung 0.01 . hasil regresi dapat diketahui nilai t hitung sebesar 8.985 dengan nilai signifikan $0,000<0,10$, maka Ho ditolak dan Ha diterima. Berdasarkan penelitian yang telah dilakukan terhadap hubungan yang kuat antara gaya komunikasi pustakawan dengan minat kunjung. Hal ini dilihat dari banyaknya mahasiswa yang memanfaatkan perpustakaan sebagai pusat sumber informasi dan belajar. Dengan adanya gaya komunikasi pustakawan yang diberikan, memberikan kemudahan berkomunikasi bagi pemustaka dengan pustakawan untuk memenuhi kebutuhan informasi yang dibutuhkan oleh pemustaka.

\section{DAFTAR PUSTAKA}

Arikunto, Suharsimi. 2010. Prosedur Penelitian: Suatu Pendekatan Peraktik. Jakarta: Rineka Cipta.

Bilson Simamora. 2008. Panduan Riset Perilaku Konsumen Jakarta: Gramedia Pustaka Utama.

Dr. Ir. Ratu Mutialela Caropeboka, M. 2017. Konsep dan aplikasi ilmu komunikasi. Yogyakarta: Andi (Anggota IKAPI).

Habir. Pengaruh Layanan Perpustakaan Terhadap Minat Kunjung Pemustaka Di Perpustakaan, (Makasar: STIKES Mega Rezky,2015), diakses dari Jurnal Ilmu Perpustakaan, Informasi dan kearsipan khizanah Al-Hikmah, 3(2), 156-17131, Oktober 2019 jam 20.00 wib

Liliweri, A. 2011 Komunikai Serba Ada Serba Makna.Jakarta: Prenada Media Group.

Robert W. Norton dan Loyd S. Pettegrew. Communication Style As An Effect Determinant Of Attraction. Vol. 4. No. 3. University of Michigan. 1977. Hlm. 260-261. Dalam http://deepblue.lib.umich.edu/bitstream/handle/2027.42/66866/10.1177_00936502770 400302.pdf? sequence $=2$. Di akses pada tanggal 30 Oktober 2019. Pukul 08.30. WIB.

Stephen W. Littlejohn, K. A. 2009.teori komunikasi. Jagakarsa, Jakarta Selatan.

Suwarno, W. 2011. perpustakaan dan buku. (Jogjakarta: AR-RUZZ MEDIA.

Wiryanto. 2004. Pengantar Ilmu Perpustakaan. Jakarta: PT. Gramedia Widiasarana Indonesia.

Yasyin, S. 1999. Kamus Lengkap Bahasa Indonesia . Surabaya: Amanah. 